\title{
DESIGN ANALYSIS OF AN UNDERGROUND TUNNEL IN TAMILNADU
}

\author{
VANUVAMALAI.A ${ }^{1}$, JAYA K P1
}

\begin{abstract}
Underground structures have gained importance in recent times all over the globe. Successful completion of such ventures hinges on accurate and realistic design which is neither optimistic nor conservative, and a balanced design is the need of the hour. The present work shows a comparative study on support design, such as Terzhagi's load theory and quantitative methods of Rock mass quality (Q), Rock Mass Rating of Bieniawski, and PLAXIS-2D Numerical modeling. The results obtained show that final support measures such as shotcreting, thickness, rock bolting, length, frequency, and requirements of steel supports are better. Based on engineering judgment and analytical approaches, realistic support measures were obtained for an access tunnel to be excavated in Nilagiri, Tamil Nadu.
\end{abstract}

Keywords: Underground Structures, RMR, Design, Support Measures, PLAXIS-2D.

\section{INTRODUCTION}

A wide range of engineering models are available to investigate the reliability of the lining in the serviceability stage of tunnels. Different types of engineering models are applied depending on the design phase of the lining, whether preliminary or final design. Engineering models can be classified as analytical, empirical, structural beam, and numerical - like FEM models. Analytical and numerical models are clear and easy to understand and to use. Solutions for tunnelling problems are obtained using analytical and numerical methods. Analytical methods estimate rock and soil behaviour after excavation and during construction of the tunnel. Due to the limitations in exploratory data, detailed analysis in on numerical methods is used to represent the sequence of construction.

${ }^{1} \mathrm{PhD}$ Student, Anna University, Department of Civil Engineering, College of Engineering Guindy,Chennai,India. e-mail:avanu23@gmail.com

${ }^{1}$ Prof., PhD., Anna University, Department of Civil Engineering, College of Engineering Guindy,Chennai,India. 


\section{SITE CHARACTERIZATION}

The access tunnel leading to the underground power house complex is $8 \mathrm{~m} \times 8 \mathrm{~m}$ in size (completed) with a length of $500 \mathrm{~m}$, which can be further extended. Based on the available information of tunneling in the neighbourhood, rock mass biotite gneiss and charnockite is traversed by foliation parallel shear fracture zones. Since some of these reaches will fall in poor-to-very poor categories, adequate temporary and permanent supports are required. Except for the initial and low cover reaches, inflow of water into the tunnel is expected to be less than $5 \mathrm{~L} / \mathrm{m}$, and many reaches are expected to be dry or only moist. The data control for predicting a forecast is also considerably restricted due to the explorations carried out along the alignment, which is limited. In general, it can be stated that tunneling will take place through good and fair rock categories, with very limited portions of poor and very poor rock mass categories.

In this present study, rock classes assigned were based on RMR rating reported by Bieniawski (1979), $[4,5]$ for design support requirements of both immediate temporary or permanent adoption. Since the project is located in a stable continental region, the seismic design load is not taken into consideration. The rock mass classes, their support, and, for tunnels less than $10 \mathrm{~m}$ diameter, vertical stresses less than $25 \mathrm{Mpa}$ and a method of construction by Drilling and Blasting are depicted in Table 1.

Table 1. The following Rock class parameters were considered in the numerical analyses.

\begin{tabular}{|c|c|c|c|c|}
\hline Rock Mass Class & Excavation & $\begin{array}{c}\text { Rock bolts of } 25 \mathrm{~mm} \\
\text { diameter }\end{array}$ & Shotcrete & Steel Sets \\
\hline $\begin{array}{c}\text { Very Good Rock I } \\
\text { RMR } \\
81-100 \\
\end{array}$ & $3 \mathrm{~m}$ of Full face advance & Only Spot bolts & None & None \\
\hline $\begin{array}{c}\text { Good Rock II } \\
\text { RMR } \\
61-80\end{array}$ & $\begin{array}{l}\text { Full face of } 1-1.5 \mathrm{~m} \text {, } \\
\text { complete support of } 20 \mathrm{~m} \\
\text { from face. }\end{array}$ & $\begin{array}{l}\text { Locally bolts in Crown- } 3 \mathrm{~m} \\
\text { long spaced } 2.5 \mathrm{~m} \text { with } \\
\text { occasional mesh. }\end{array}$ & $\begin{array}{l}50 \mathrm{~mm} \text { in Crown } \\
\text { wherever required. }\end{array}$ & None \\
\hline $\begin{array}{l}\text { Fair Rock III } \\
\text { RMR 41-60 }\end{array}$ & $\begin{array}{l}\text { Top heading and benching } \\
\text { of } 3 \mathrm{~m} \text { in advance commence } \\
\text { support after every blast } \\
\text { complete support of } 10 \mathrm{~m} \\
\text { from face. }\end{array}$ & $\begin{array}{l}\text { Systematic bolts of } 4 \mathrm{~m} \text { long } \\
\text { spaced between } 1.5-2.0 \mathrm{~m} \text { in } \\
\text { crown and walls with mesh } \\
\text { in Crown. }\end{array}$ & $\begin{array}{ll}50-100 \mathrm{~mm} & \text { in } \\
\text { crown 30mm } & \text { in } \\
\text { sidewalls. } & \end{array}$ & None \\
\hline $\begin{array}{c}\text { Poor Rock IV } \\
\text { RMR } \\
21-40\end{array}$ & $\begin{array}{l}\text { Top heading and bench. } \\
\text { Advance commence } \\
\text { support of } 1-1.5 \mathrm{~m} \text { in } \\
\text { heading install support }\end{array}$ & $\begin{array}{l}\text { Systematic bolts of } 4-5.0 \mathrm{~m} \\
\text { long spaced } 1-1.5 \mathrm{~m} \text { in } \\
\text { Crown and walls with wire } \\
\text { mesh. }\end{array}$ & $\begin{array}{l}100-150 \mathrm{~mm} \text { in } \\
\text { crown and } 100 \mathrm{~mm} \\
\text { in side walls. }\end{array}$ & $\begin{array}{l}\text { Light ribs spaced } \\
1.5 \mathrm{~m} \text { wherever } \\
\text { required. }\end{array}$ \\
\hline
\end{tabular}




\begin{tabular}{|c|l|l|l|l|}
\hline & $\begin{array}{l}\text { concurrently with } \\
\text { excavation of 10m from } \\
\text { face. }\end{array}$ & & & \\
\hline $\begin{array}{c}\text { Very poor rock V } \\
\text { RMR }<20\end{array}$ & $\begin{array}{l}\text { Multiple drifts, 0.5m to } \\
1.5 \mathrm{~m} \text { advance in top } \\
\text { heading install support } \\
\text { concurrently } \begin{array}{l}\text { Systematic bolting of 5-6m } \\
\text { long space of 1-1.5m } \\
\text { excavation. Shotcrete as } \\
\text { boon as possible after } \\
\text { with wire mesh. Bolt invert. } \\
\text { excavation. }\end{array}\end{array}$ & $\begin{array}{l}150-200 \mathrm{~mm} \text { in } \\
\text { sides and 50mm on } \\
\text { face. }\end{array}$ & $\begin{array}{l}\text { Medium to heavy } \\
\text { ribs spaced 7.5m } \\
\text { with steel lagging } \\
\text { and fore poling if } \\
\text { required. Close } \\
\text { invert. }\end{array}$ \\
\hline
\end{tabular}

\section{NEW AUSTRIAN TUNNELING METHOD (NATM)}

Based on the concept of minimum intervention and stabilization of tunnels by controlled stress release, an approach of "design as you proceed" (rather than having a fixed design) is selected [1]. The emphasis on installation of systematic rock bolting in tandem with shotcrete lining allows limited deformation, but prevents loosening of the rock mass. It is particularly highly advantageous in nonsqueezing ground conditions, as in the instant case where shotcrete has to be applied within the standup time of the ground. The grounds are identified based on rock mass rating (RMR) obtained by geological and geotechnical investigations. This approach is the most commonly used method in construction of modern tunnels all over the world and preferred in view of its simplicity \& adoptability.

Table 2. Relation between RMR \& Ground types with support measures.

\begin{tabular}{|c|c|l|}
\hline RMR & Ground Type & \multicolumn{1}{|c|}{ Support Requirements } \\
\hline $81-100$ & GT 1 & No Rock Bolt, No Shotcrete. \\
\hline $61-80$ & GT 2 & No Shotcrete, 3m length Rock Bolt @ 3m c/c (as per Site Conditions. \\
\hline $41-60$ & GT 3 & $50 \mathrm{~mm}$ Shotcrete, 3m length Rock Bolt @ 3m c/c. \\
\hline $21-40$ & GT 4 & $\begin{array}{l}75 \mathrm{~mm} \text { Shotcrete \& 4m length Rock Bolt @ 2m c/c \& Pantex Lattice } \\
\text { Girder P50-20-30 @ 1.0m c/c. }\end{array}$ \\
\hline Less than 20 & GT 5 & $\begin{array}{l}75 \mathrm{~mm} \text { Shotcrete with wire mesh \& 4m length Rock Bolt @ 2m c/c \& } \\
\text { Steel Girder ISMB300 @ 500 c/c with Backfilling. }\end{array}$ \\
\hline
\end{tabular}




\section{GEOTECHNICAL DESIGN PARAMETERS \& NUMERICAL ANALYSES}

The geotechnical design parameters for analyses are gathered from field and laboratory test data, and are based on the experience in local and similar ground/terrain conditions. The parameters used in the static design and analyses are depicted in the Table 3.

Five numerical analyses were performed using the finite element software PLAXIS-2D[7] on simplified 2-dimensional models, assuming plane strain conditions, in order to check the results of the analytical model for different support categories with high overburden, ground type, and maximum overburden of $30 \mathrm{~m}$ over the tunnel crown or 3D cover of the access tunnel. The geometry of the tunnel with its main primary support elements was taken from the design blueprints. In the numerical modelling, a "homogeneous" underground situation and "plain" ground surface conditions were assumed. The overburden was simulated by means of a $30 \mathrm{~m}$ thick layer introduced in the model. The model boundaries were determined at a distance of approximately 3 times the tunnel diameter to the outer tunnel circumference. The numerical model was therefore about $80 \mathrm{~m}$ wide and $57 \mathrm{~m}$ in height, including the over burden layer $30 \mathrm{~m}$ in thickness. The model was fixed at the lower boundary in the $\mathrm{x}$ - and $\mathrm{y}$-directions and at the lateral boundaries in the $\mathrm{x}$-direction by allowing the upper boundary to move freely. Additionally, primary lining of the tunnel was fixed at the top of the symmetrical axis against rotation (= symmetrical boundary conditions for plates).

The mesh generation was done automatically by the finite element program with 15-noded triangular shaped elements. Excavation of approximately $8 \mathrm{~m}$ around the mesh of the tunnel was refined.

Table 3. The following rock mass parameters were considered in the numerical analyses.

\begin{tabular}{|c|c|c|c|c|c|c|}
\hline $\begin{array}{c}\text { Ground } \\
\text { Type }\end{array}$ & $\begin{array}{c}\text { Various } \\
\text { Rock Class }\end{array}$ & $\begin{array}{c}\gamma \\
{\left[\mathrm{kN} / \mathrm{m}^{3}\right]}\end{array}$ & $\begin{array}{c}\Phi \\
{\left[{ }^{\circ}\right]}\end{array}$ & $\begin{array}{c}\mathrm{c} \\
{[\mathrm{MPa}]}\end{array}$ & $\begin{array}{c}\mathrm{E} \\
{[\mathrm{GPa}]}\end{array}$ & $\begin{array}{c}\mathrm{v} \\
{[-]}\end{array}$ \\
\hline GT1 & Very Good & $28-30$ & $40-50$ & 0.4 & $70-150$ & $0.1-0.2$ \\
& & 27 & 43 & & 90 & 0.15 \\
\hline GT2 & Good & $26-30$ & $30-45$ & 0.35 & $10-100$ & $0.1-0.2$ \\
& & 27 & 40 & & 70 & 0.15 \\
\hline GT3 & Fair & $26-28$ & $23-35$ & 0.25 & $20-50$ & $0.15-0.25$ \\
& & 27 & 30 & & 50 & 0.20 \\
\hline GT4 & Poor & $26-28$ & $21-28$ & 0.15 & $10-30$ & $0.15-0.25$ \\
& & 26 & 20 & & 30 & 0.20 \\
\hline GT5 & Very Poor & $26-28$ & $12-18$ & 0.1 & $6-25$ & $0.15-0.25$ \\
& & 26 & 13 & & 20 & 0.20 \\
\hline
\end{tabular}

$\gamma \quad$ Specific weight 


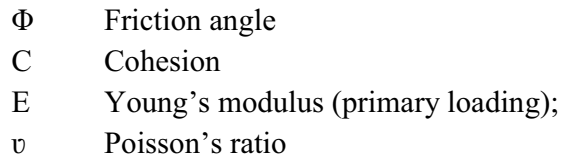

The rock mass was simulated with the linear elastic and perfectly plastic Mohr-Coulomb constitutive model. Tensile stresses were generally not allowed in the analysis. The parameters were valid for drained conditions. It was assumed that drainage measures dissipate possible pore pressures.

The Young's modulus (E) indicated above was used to describe the deformation behaviour of the rock mass for primary loading conditions. Below the excavation level, the modulus was set as 3 times higher to consider more realistic heave effects caused by excavation.

\subsection{SHOTCRETE}

Shotcrete of M25with/without wire mesh is designed for primary lining of support categories. The shotcrete lining was modelled with linear elastic plate elements and the thickness varied in the support categories. The modulus of elasticity was estimated with an average value of $2500 \mathrm{MPa}$ from previous projects by considering the gain of strength over time and the shrinking and creeping effects. The properties of shotcrete considered in the analyses are given in Table 4.

Table 4. Shotcrete parameters considered in the numerical analyses.

\begin{tabular}{|l|c|}
\hline Specific weight & $25\left[\mathrm{kN} / \mathrm{m}^{3}\right]$ \\
\hline E-Modulus & $2.5 \mathrm{E}+06\left[\mathrm{kN} / \mathrm{m}^{2}\right]$ \\
\hline Poisson's ratio & 0.20 \\
\hline
\end{tabular}

\subsubsection{SHOTCRETE WITH STEEL SETS}

Steel sets/lattice girders are installed in the shotcrete primary lining. The shotcrete thicknesses as well as the type of the lattice girders (and the spacing) varied in the different support categories. The lining was modelled with linear elastic plate elements.

\section{ROCK BOLTS}

Rock bolts are modelled as "geogrid" elements of an elastoplastic type of material which can sustain only tensional (but not compressive) forces. The main input parameters considered are the extensional stiffness and the maximum axial force per each meter of tunnel. The part of the extensional stiffness 
carried by the grouted body is not considered. The following material properties for rock bolts [9] have been considered.

Table 5. Rock bolt parameters considered in the numerical analyses.

\begin{tabular}{|l|c|c|c|c|}
\hline Type & & & Frictional bolts & Grouted bolts \\
\hline Min.Breaking Load & NUlt & {$[\mathrm{kN}]$} & 200 & 250 \\
\hline Yielding Load & $\mathrm{Np}(1)$ & {$[\mathrm{kN}]$} & 180 & 220 \\
\hline E-Modulus & $\mathrm{E}$ & {$\left[\mathrm{kN} / \mathrm{m}^{2}\right]$} & $2.1 \mathrm{E}+08$ & $2.1 \mathrm{E}+08$ \\
\hline
\end{tabular}

\section{INTERFACE ELEMENTS}

Interface elements were arranged around the outer surface of the primary lining of the tunnel into the surrounding rock by considering the rock-structure interaction. In the interfaces, the friction angle of the surrounding rock was reduced by a factor $\mathrm{R}_{\text {inter }}$ which corresponds to $2 / 3 \Phi$, where $\Phi$ is the friction angle.

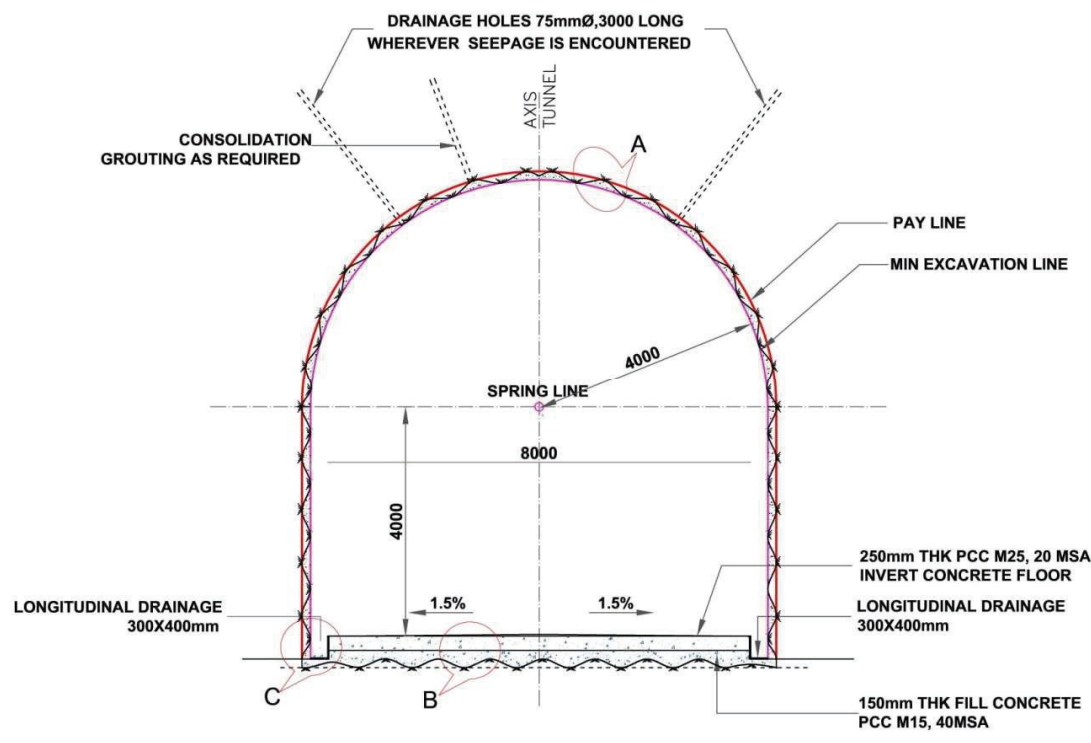



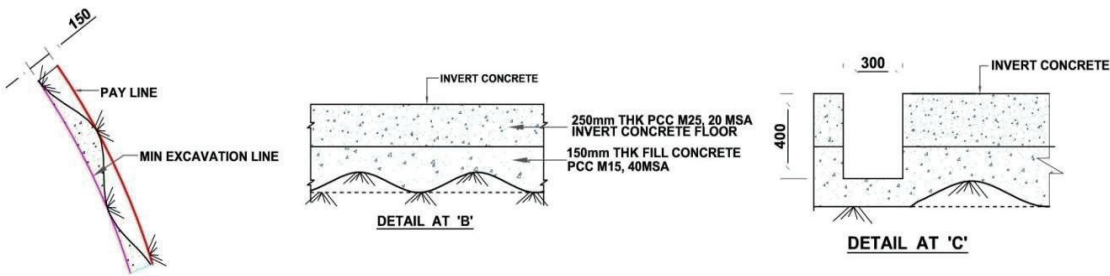

DETAIL AT 'A'

Fig. 1. Typical cross section for a bi-directional single-tube tunnel without an invert

\section{RESULTS AND DISCUSSIONS}

The analysis consists of various parametric studies to determine the most critical case with respect to the water table, presence of surcharge, $\mathrm{K} 0$ value, lining thickness, and the depth of the tunnel. The maximum bending moment and its corresponding axial force, shear force, and displacement values are calculated from the PLAXIS results. The water table level is considered below the invert portion of the tunnel. The surcharge and $\mathrm{K} 0$ values are given during modelling in PLAXIS, and will be automatically generated based on the conditions of the soil properties. Lining thickness is mentioned in Table 6. The depth of the tunnel cover once changing the tunnel behaviour also changed based on the stress conditions.

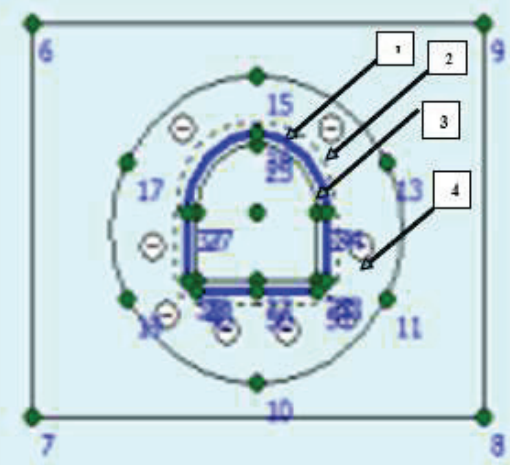

Fig.2. Model diagram of Very Good Rock 1.Lining, 2. Pay line, 3.Min excavation line, 4.Soil property

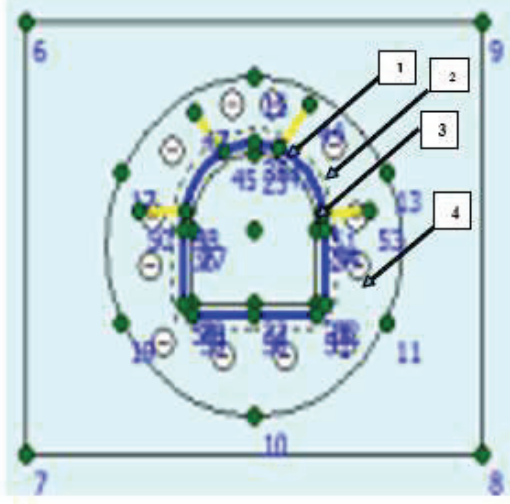

Fig.3. Model diagram of Good Rock 1.Lining, 2. Pay line, 3.Min excavation line, 4.Soil property 


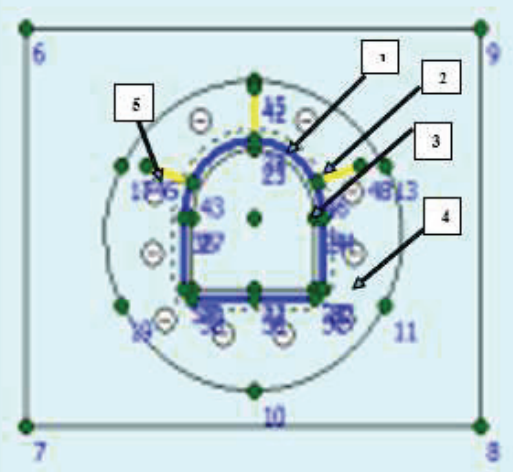

Fig.4. Model diagram of Fair Rock 1. Lining,

2. Pay line, 3.Min excavation line, 4 .Soil property,

5. Rock Bolt

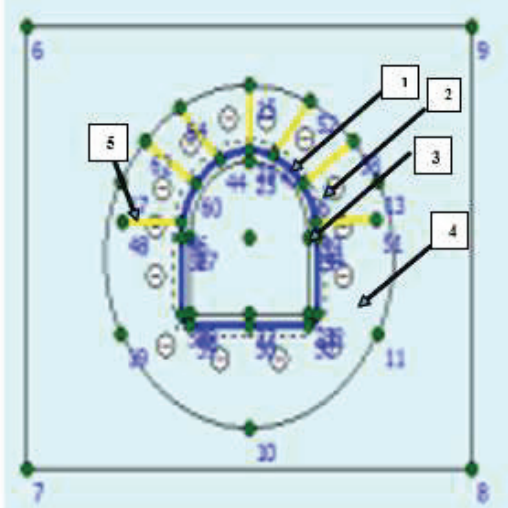

Fig.5. Model diagram of Poor Rock 1.Lining, 2. Pay line, 3 .Min excavation line, 4 .Soil property 5. Rock Bolt

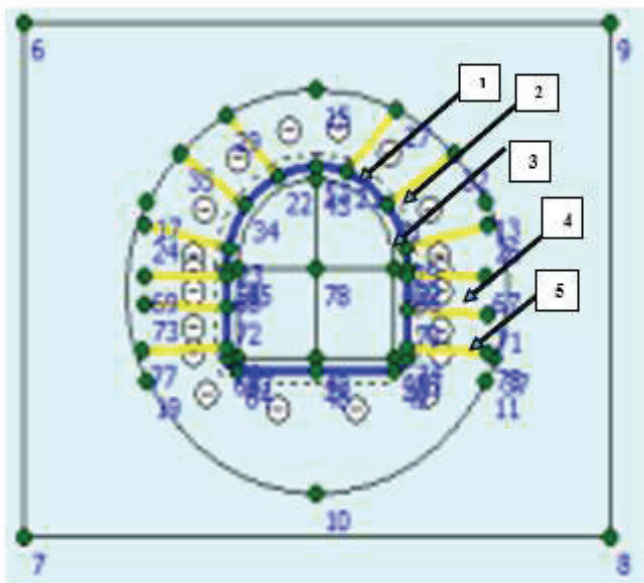

Fig.6. Model diagram of Very Poor Rock 1.Lining, 2. Pay line, 3.Min excavation line, 4.Soil property, 5. Rock Bolt 


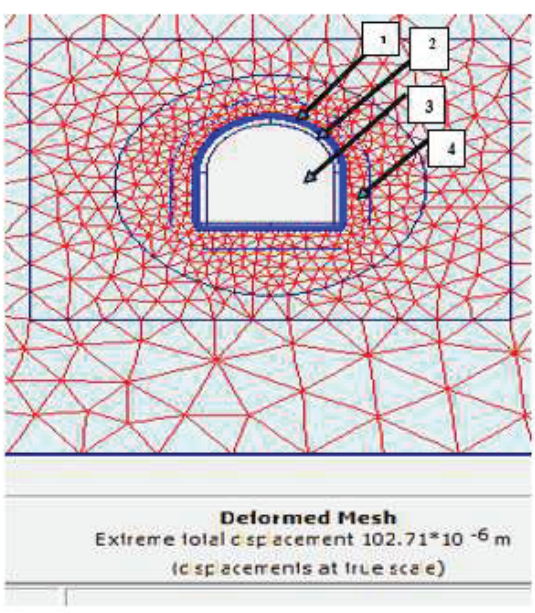

Fig.7. Displacement diagram of Very Good Rock 1. Lining, 2. Min excavation line, 3.Excavated Portion, 4. Meshing.

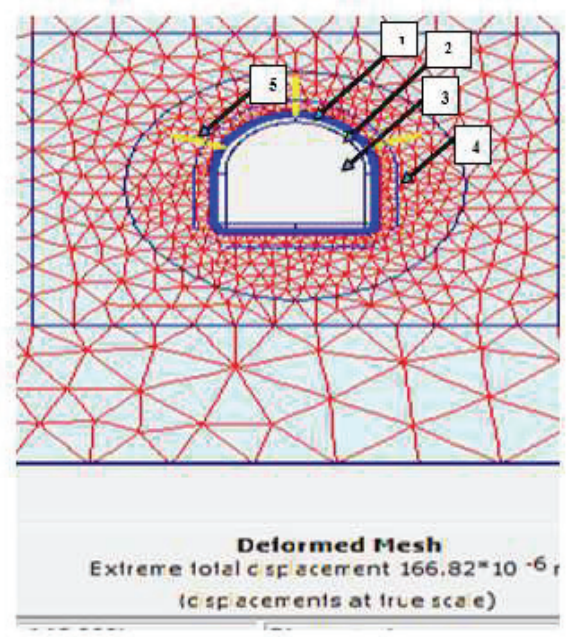

Fig.9. Displacement diagram of Fair Rock 1. Lining, 2. Min excavation line, 3.Excavated Portion, 4. Meshing, 5. Rock Bolt

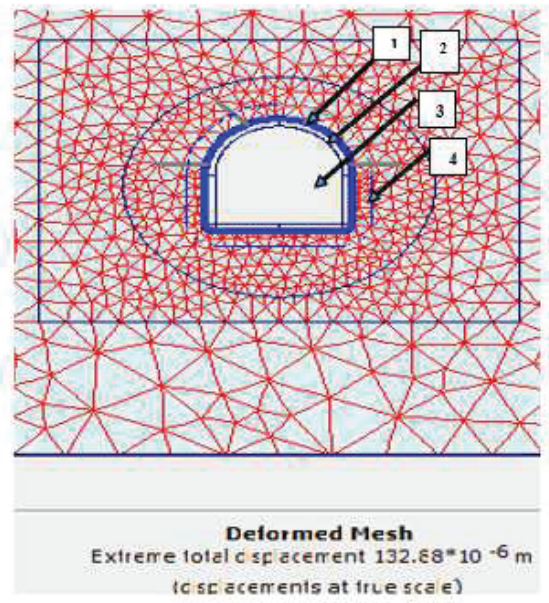

Fig.8. Displacement diagram of Good Rock 1.Lining, 2. Min excavation line, 3.Excavated Portion, 4.Meshing

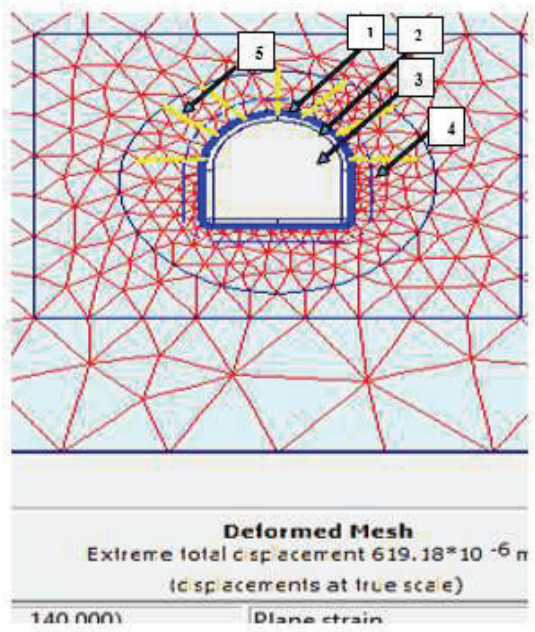

Fig.10. Displacement diagram of Poor Rock 1.Lining, 2. Min excavation line, 3.Excavated Portion, 4.Meshing, 5. Rock Bolt 


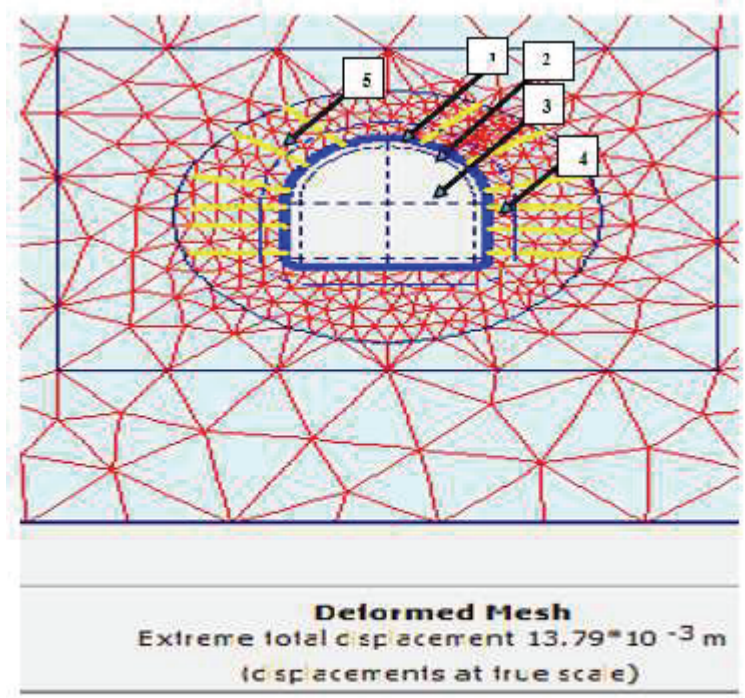

Fig.11. Displacement diagram of Very Poor Rock 1.Lining,

2. Min excavation line, 3.Excavated Portion, 4.Meshing,

5. Rock Bolt

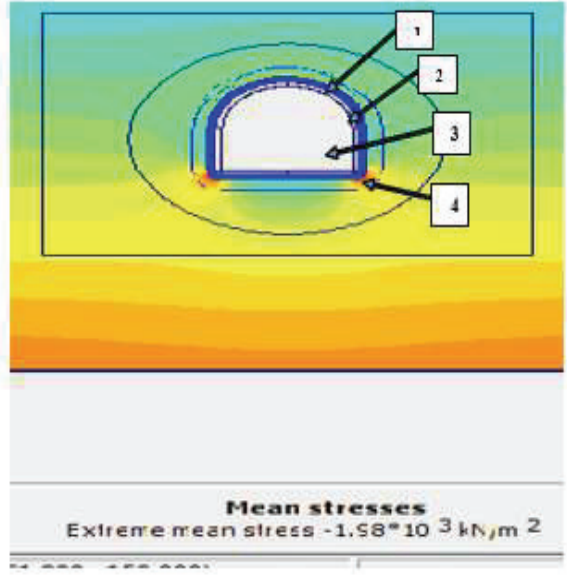

Fig.12. Stress diagram of Very good Rock

1. Lining, 2. Min excavation line, 3.Excavated Portion, 4. Extreme stress portion.

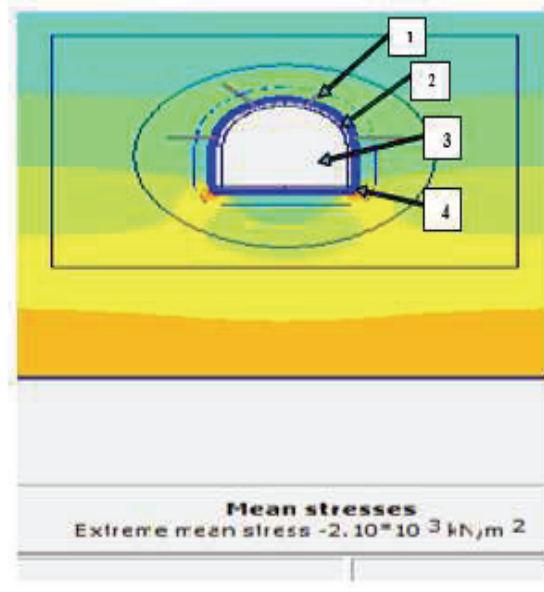

Fig.13. Stress diagram of Good Rock 1.Lining, 2. Min excavation line, 3.Excavated Portion, 4. Extreme stress portion. 

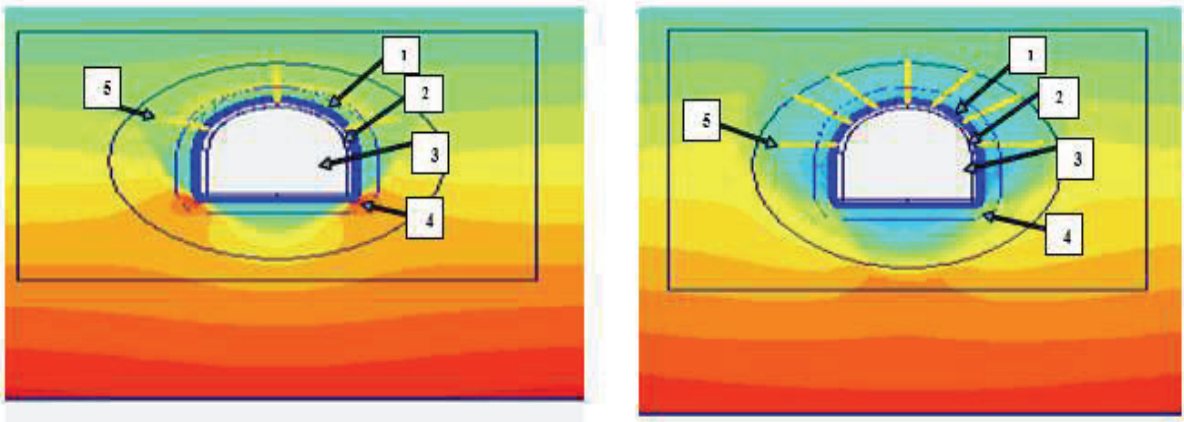

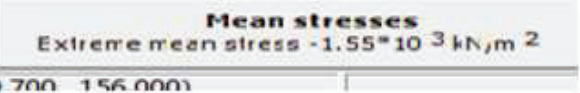

Fig.14. Stress diagram of Fair Rock

1. Lining, 2. Min excavation line, 3.Excavated Portion, 4. Extreme stress portion, 5. Rock Bolt

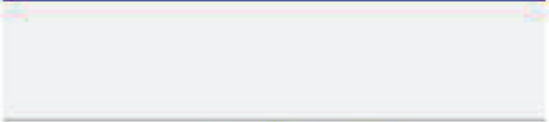

\section{Mean stresses}

Extreme rean stress $-1.53^{*} 10^{3} \mathrm{kN}, \mathrm{m}^{2}$

Fig.15. Stress diagram of Poor Rock

1.Lining, 2. Min excavation line, 3.Excavated Portion, 4. Extreme stress portion, 5. Rock Bolt

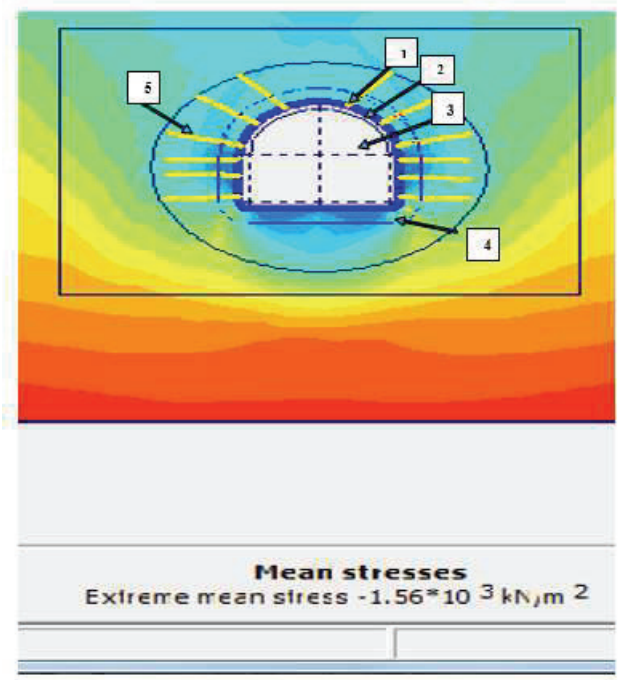

Fig.16. Stress diagram of Very Poor Rock 1.Lining,

2. Min excavation line, 3.Excavated Portion, 4.Stress portion,

5. Rock Bolt

The results are depicted in Figs. 1-16 showing that maximum vertical deformation of approximately $0.166 \mathrm{~mm}$ occurs at the top heading of the tunnel. The maximum vertical heave of the invert is approximately $0.133 \mathrm{~mm}$. 
The maximum horizontal deformation at the lower part of the bench is approximately $0.11 \mathrm{~mm}$, occurring in very good, good, and fair rock conditions. The maximum in poor and very poor rock conditions is $0.619 \mathrm{~mm}$ and $13 \mathrm{~mm}$.

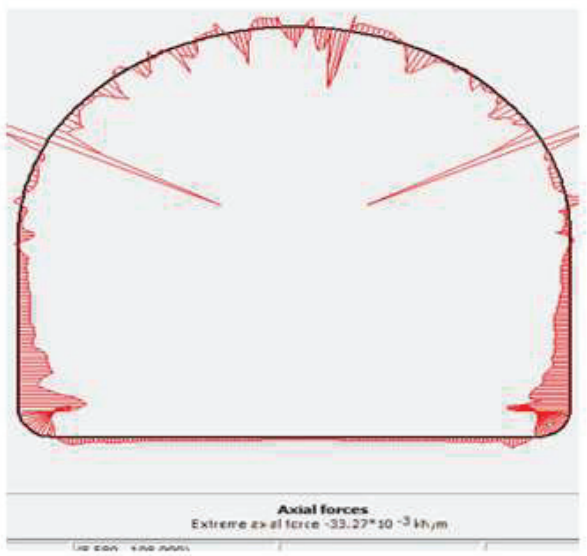

Fig.17.Figure shows Fair Rock Axial force

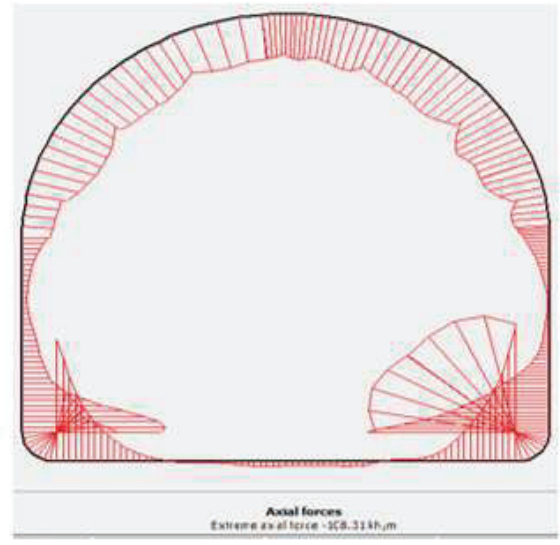

Fig.18. Figure shows Poor Rock Axial force

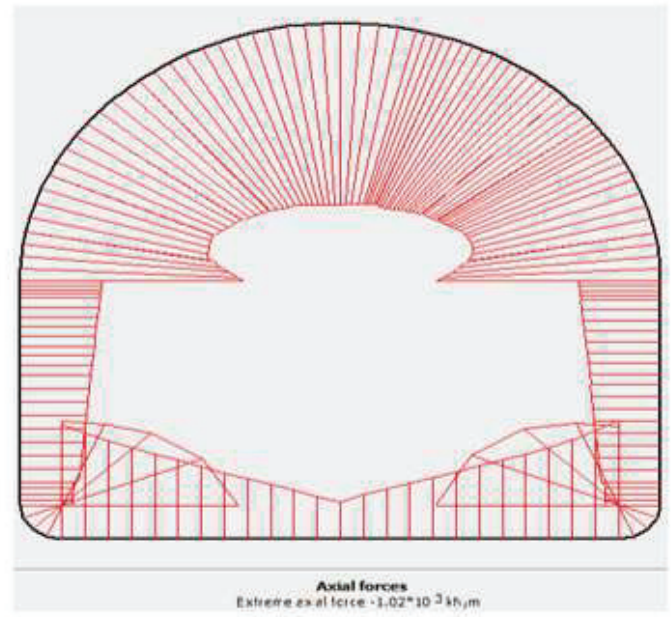

Fig.19. Figure shows Very Poor Rock Axial force 


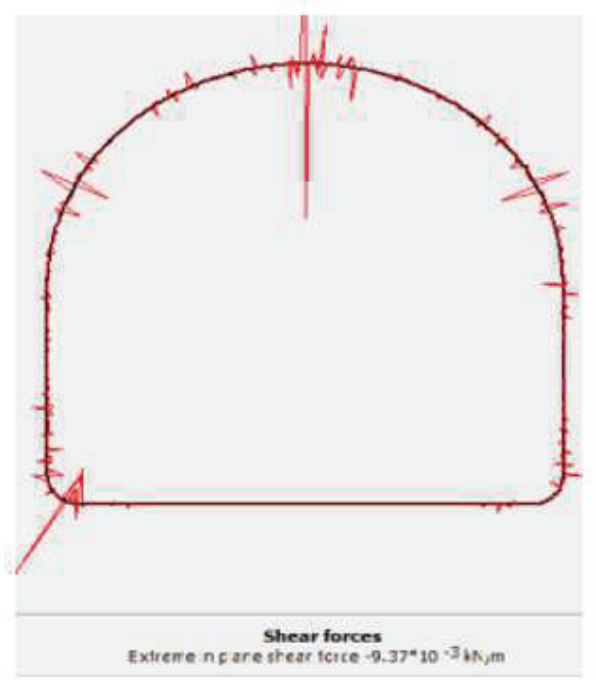

Fig.20.Figure shows Fair Rock Shear force

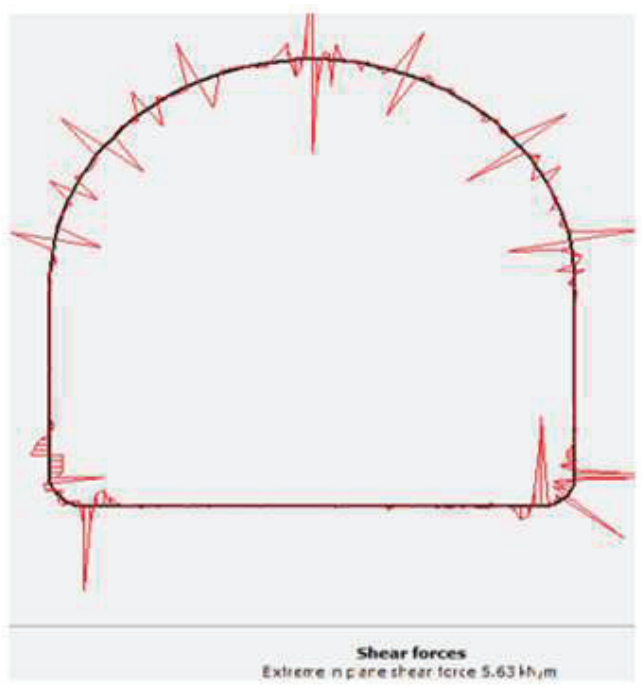

Fig.21. Figure shows Poor Rock Shear force

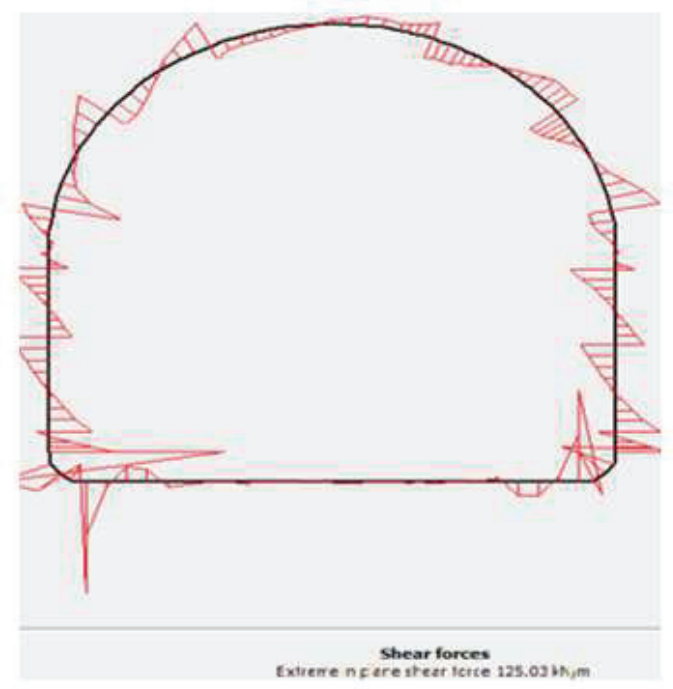

Fig.22. Figure shows Very Poor Rock Shear force

Figs. 23-25 show bending moments of the primary lining (final step). Figs. 17-22 show the internal forces of the final calculation step. A maximum normal force of approximately $108 \mathrm{KN}$ and $1002 \mathrm{KN}$ is determined for the primary lining. Due to the closure of the primary lining, no singularities occur in this numerical analysis. The maximum bending moments are determined to be about $0.316 \mathrm{kNm}$ 
and $19 \mathrm{kNm}$, respectively. The primary lining is designed in sections by providing radial bolting in the rock bolts of the final calculation step. It can be observed that the rock bolts reach the ultimate level in most parts of the tunnel. For the analyses, the correlation between ground types, behaviour types, ranges of overburden, and support categories are investigated, as shown in Table 6. Fault zones are not calculated via the simple analytical method due to the limited thickness of the fault zone, which leads to significantly lower displacements and loading of the tunnel lining than in the $2 \mathrm{D}$ analysis.

\section{CONCLUSIONS \& RECOMMENDATIONS}

Modern finite element software enables very detailed and high-resolution 2D analysis to simulate realistic scenarios. Variation in the distribution of the above-designed parameters along the cross section of the tunnel is also observed. The design support measures obtained are realistic and rigorously analysed through various methods of support design. However, they might be subjected to marginal revisions based on the detailed geological and geotechnical assessments of the tunnelling media taken up during construction. As a comparison of support measures by various authors and methods, PLAXIS 2D was used in this study, and the results are provided in Table 6:

\begin{tabular}{|c|c|c|c|c|c|}
\hline $\begin{array}{l}\text { Rock } \\
\text { Class } \\
\end{array}$ & Terzaghi (1946).,[10] & $\begin{array}{l}\text { Barton et al. } \\
(1974) .,[2,8]\end{array}$ & $\begin{array}{l}\text { Bieniawski(1973)., } \\
{[3]}\end{array}$ & $\begin{array}{l}\text { PLAXIS } \\
2 \mathrm{D}[7]\end{array}$ & $\begin{array}{l}\text { Recommended in this } \\
\text { work }\end{array}$ \\
\hline I & $\begin{array}{l}\text { Hard \&Intact. Light } \\
\text { Lining required only } \\
\text { in the case of } \\
\text { spalling/popping }\end{array}$ & $\begin{array}{l}3.8 \mathrm{~m} \text { long bolt } \\
\text { and Spacing of } \\
2.7 \mathrm{~m}\end{array}$ & $\begin{array}{l}\text { Occasional spot } \\
\text { bolts }\end{array}$ & $\begin{array}{l}\text { No lining / } \\
\text { No Rock Bolt }\end{array}$ & $\begin{array}{l}\text { Occasional Spot bolts } \\
\text { as required }\end{array}$ \\
\hline II & $\begin{array}{l}\text { Hard stratified and } \\
\text { Schistose. Only light } \\
\text { support is needed in } \\
\text { case of Spalling }\end{array}$ & $\begin{array}{l}3.8 \mathrm{~m} \quad \text { long } \\
\text { boltand } 2.5 \mathrm{~m} \\
\text { Spacing }\end{array}$ & $\begin{array}{l}\text { Locally bolts in } \\
\text { Crown-3m and } \\
\text { long space of } 2.5 \mathrm{~m} \\
\text { with occasional } \\
\text { Mesh }\end{array}$ & $\begin{array}{l}\text { No lining / } \\
\text { Bolt } 3 \text { no’s @ } \\
\text { 3m spacing }\end{array}$ & $\begin{array}{l}\text { Spot bolt } 3.0 \mathrm{~m} \text { long as } \\
\text { required, shotcrete } \\
50 \mathrm{~mm} \text { as required } \\
\text { locally, Consolidation } \\
\text { grouting as required } \\
\text { locally, Drainage hole } \\
\text { of } 75 \mathrm{~mm} \text { diameter, } \\
3 \mathrm{~m} \text { length as required } \\
\text { locally }\end{array}$ \\
\hline III & $\begin{array}{l}\text { Massive and } \\
\text { moderately jointed. } \\
\text { No side pressure. }\end{array}$ & $\begin{array}{l}40 \mathrm{~mm} \text { thick } \\
\text { steel fiber } \\
\text { reinforced } \\
\text { shotcrete. And } \\
3.8 \mathrm{~m} \text { long bolt } \\
\text { and a spacing } \\
2.3 \mathrm{~m}\end{array}$ & $\begin{array}{l}\text { Systematic bolts of } \\
4 \mathrm{~m} \text { and long space } \\
\text { between } 1.5-2.0 \mathrm{~m} \\
\text { in crown and walls } \\
\text { with mesh in } \\
\text { Crown }\end{array}$ & $\begin{array}{l}50 \mathrm{~mm} \\
\text { Shotcrete \& } \\
3 \mathrm{~m} \mathrm{length} \\
\text { Rock Bolt@ } \\
2.5 \mathrm{~m} \mathrm{c} / \mathrm{c}\end{array}$ & $\begin{array}{l}\text { Fully grouted Rock } \\
\text { bolts } 3 \mathrm{~m} \text { long, } 1.5 \mathrm{~m} \\
\text { spacing, Staggered } \\
\mathrm{M}-30,50 \mathrm{~mm} \text { thick } \\
\text { shotcrete, } \\
\text { consolidation grouting } \\
\text { and drainage holes } \\
75 \mathrm{~mm} \text { diameter, } 3 \mathrm{~m} \\
\text { length as required. }\end{array}$ \\
\hline IV & $\begin{array}{l}\text { Moderate blocky and } \\
\text { seamy [6]. No side } \\
\text { pressure }\end{array}$ & $\begin{array}{lr}50 \mathrm{~mm} & \text { thick } \\
\text { Steel fiber } \\
\text { reinforced }\end{array}$ & $\begin{array}{l}\text { Systematic bolts of } \\
4-5 \mathrm{~m} \text { and space } \\
\text { between } 1-1.5 \mathrm{~m} \text { in }\end{array}$ & $\begin{array}{l}75 \mathrm{~mm} \text { thick } \\
\text { shotcrete, } 4 \mathrm{~m} \\
\text { long bolt and }\end{array}$ & $\begin{array}{ll}\text { Alternate 1: } & \text { M30 } \\
\text { shotcrete with } & \text { wire } \\
\text { mesh, 4m long rock }\end{array}$ \\
\hline
\end{tabular}




\begin{tabular}{|c|c|c|c|c|c|}
\hline & & $\begin{array}{l}\text { shotcrete } \\
\text { with } 3.8 \mathrm{~m} \text { long } \\
\text { bolts and } \\
\text { Spacing of } \\
1.5 \mathrm{~m}\end{array}$ & $\begin{array}{l}\text { crown and walls } \\
\text { with wire mesh }\end{array}$ & $2 \mathrm{~m}$ spacing & $\begin{array}{l}\text { bolt, spacing at } 2.0 \mathrm{~m} \\
\text { with lattice girder P50- } \\
20-30 @ 1.0 \mathrm{M} \mathrm{C} / \mathrm{C} \\
\text { Alternate2: 75mm } \\
\text { shotcrete with wire } \\
\text { mesh and ISMB } 300 \\
@ 1.00 \mathrm{mmC} / \mathrm{C} \text {, Rock } \\
\text { bolt } 4 \mathrm{~m} @ 1.50 \mathrm{~m} \text { c/c }\end{array}$ \\
\hline $\mathrm{V}$ & $\begin{array}{l}\text { Very blocky and } \\
\text { seamy. Little or no } \\
\text { side pressure }\end{array}$ & $\begin{array}{l}120-150 \mathrm{~mm} \\
\text { shotcrete Steel } \\
\text { fibers with } \\
3.8 \mathrm{~m} \text { long } \\
\text { bolts at a } \\
\begin{array}{l}\text { spacing } \\
1.2 \mathrm{~m}\end{array}\end{array}$ & $\begin{array}{l}\text { Systematic bolts of } \\
5-6 \mathrm{~m} \text { and space } \\
\text { between } 1-1.5 \mathrm{~m} \text { in } \\
\text { Crown and walls } \\
\text { with wire mesh. } \\
\text { Bolt invert }\end{array}$ & $\begin{array}{l}75 \mathrm{~mm} \text { thick } \\
\text { shotcrete, } 4 \mathrm{~m} \\
\text { long, @2m } \\
\text { spacing }\end{array}$ & $\begin{array}{l}\text { Shotcrete } 75 \mathrm{Mm} \text { thick } \\
\text { with wire mesh, 5m } \\
\text { long bolts at a spacing } \\
\text { of } 1.5 \mathrm{~m} \& \text { Steel girder } \\
\text { ISMB 300× } 140 @ \\
500 \mathrm{mmc} / \mathrm{c}\end{array}$ \\
\hline
\end{tabular}

A thorough comparison of supports across various methods prevalent in general practice using conventional wisdom is also considered for the final support measures. As the superincumbent load is below $500 \mathrm{~m}$ in competent media, no overstressing or squeezing conditions are discussed. This study is based on the detailed design carried out by collecting field data and applied data, however, variations will be encountered during the actual tunneling process. As a compromise, conducting in situ tests is recommended as a pre-construction activity in order to obtain more realistic conditions, and also to validate the present design work which was carried out based primarily on lab data.

\section{ACKNOWLEDGEMENTS}

The first author acknowledges the financial assistance provided by Anna University, Chennai, through the Anna Centenary Research Fellowship research grant and would also like to thank Mr.V.Balachandran, GSI Retd, (HoD), Chennai, for his moral support. 


\section{REFERENCES}

1. Austrian Society for Geomechanics, Guideline for the geotechnical design of underground structures with conventional excavation. 2001, 2008, 2009.

2. Barton, N. Lien., and Lunde J. (1974). Engineering classification of Rock masses for the Design of tunnel Supports, Rock Mechanics Springer-Vertag vol.6.

3. Bieniawski, Z.T. (1973). Engineering Classification of Jointed Rock masses, The Civil Engineer in South Africa.

4. Bieniawski, Z.T. (1979). the Geomechanics Classification in Rock Engineering Applications, Intl.Soc. For Rock. Mech.

5. Bieniawski, Z.T. (1989). Engineering Rock Mass Classification John Wiley \&sons.

6. Brekke, T.L. (1968). Blocky and seamy rock in tunnelling Bull.Assoc.Eng.Geol Vol.5.

7. Brinkgreve R.B.J. et al., (2002), PLAXIS 2D- Version 8 User Manual, A.A. Balkema Publishers.

8. Grimstad, E. and Barton, N. (1993) Updating of the Q system for NMT-Intl symposium on sprayed concreteModern use of wet mix sprayed concrete for underground support.

9. Hoek, E. and Brown, E.T. (1982). Underground excavation in rocks Institution of Mining and Metallurgy, London.

10. Terzhagi, K. (1946). Rock defects and load on tunnel supports, Introduction to Rock tunnelling with steel supports published by Proctor, Ohio, USA. 


\section{LIST OF FIGURES AND TABLES:}

Fig. 1. Typical cross section for bi-directional single tube tunnel without invert

Rys. 1. Typowy przekrój dla dwukierunkowego tunelu z pojedynczą rurą, bez odwracania

Fig.2. Model diagram of Very Good Rock

Rys. 2. Wzorcowy wykres bardzo dobrej skały

Fig.3. Model diagram of Good Rock

Rys. 3. Wzorcowy wykres dobrej skały

Fig.4. Model diagram of Fair Rock

Rys. 4. Wzorcowy wykres przeciętnej skały

Fig.5. Model diagram of Poor Rock

Rys. 5. Wzorcowy wykres słabej skały

Fig.6. Model diagram of Very Poor Rock

Rys. 6. Wzorcowy wykres bardzo słabej skały

Fig.7. Displacement diagram of Very Good Rock

Rys. 7. Wykres przemieszczenia bardzo dobrej skały

Fig.8. Displacement diagram of Good Rock

Rys. 8. Wykres przemieszczenia dobrej skały

Fig.9. Displacement diagram of Fair Rock

Rys. 9. Wykres przemieszczenia przeciętnej skały

Fig.10.Displacement diagram of poor Rock

Rys. 10.Wykres przemieszczenia słabej skały

Fig.11.Displacement diagram of Very poor Rock

Rys. 11.Wykres przemieszczenia bardzo słabej skały

Fig.12. Stress diagram of Very good Rock

Rys. 12. Wykres naprężeń bardzo dobrej skały

Fig.13. Stress diagram of good Rock

Rys. 13. Wykres naprężeń dobrej skały

Fig.14. Stress diagram of fair Rock

Rys. 14. Wykres naprężeń przeciętnej skały

Fig.15. Stress diagram of poor Rock

Rys. 15. Wykres naprężeń słabej skały

Fig.16. Stress diagram of Very poor Rock

Rys. 16. Wykres naprężeń bardzo słabej skały

Fig.17.Figure shows Fair Rock Axial force

Rys. 17. Rysunek przedstawiający siłę osiową przeciętnej skały

Fig.18.Figure shows poor Rock Axial force 
Rys. 18. Rysunek przedstawiający siłę osiową słabej skały

Fig.19.Figure shows very poor Rock Axial force

Rys. 19. Rysunek przedstawiający siłę osiową bardzo słabej skały

Fig.20.Figure shows Fair Rock shear force

Rys. 20. Rysunek przedstawiający siłę ścinającą przeciętnej skały

Fig.21.Figure shows poor Rock shear force

Rys. 21. Rysunek przedstawiający siłę ścinającą słabej skały

Fig.22.Figure shows very poor Rock shear force

Rys. 22. Rysunek przedstawiający siłę ścinającą bardzo słabej skały

Fig.23.Figure shows Fair Rock Bending Moment

Rys. 23. Rysunek przedstawiający moment zginający przeciętnej skały

Fig.24. Figure shows Poor Rock Bending Moment

Rys. 24. Rysunek przedstawiający moment zginający słabej skały

Fig.25. Figure shows Very Poor Rock Bending Moment

Rys. 25. Rysunek przedstawiający moment zginający bardzo słabej skały 


\section{ANALIZA PROJEKTOWA TUNELU PODZIEMNEGO W TAMILNADU}

Slowa kluczowe: Technologia przestrzeni podziemnej, RMR, Projekt, Środki wsparcia, Plaxis 2D.

\section{STRESZCZENIE:}

W ostatnim czasie technologia przestrzeni lub podziemne struktury zyskały na znaczeniu na całym świecie. Sukces w realizacji takich przedsięwzięć zależy od dokładnego i realistycznego projektu, który nie jest ani optymistyczny, ani konserwatywny, a niezwykle potrzeby jest obecnie zbalansowany projekt. W niniejszej pracy przedstawiono badanie porównawcze dotyczące projektu wsparcia, takie jak teoria obciążenia Terzhagiego oraz ilościowe metody jakości ośrodka skalnego $(\mathrm{Q})$, oceny ośrodka skalnego według Bieniawskiego oraz modelowanie numeryczne Plaxis $2 \mathrm{D}$. Uzyskane wyniki pokazują, że końcowe środki wsparcia, takie jak torkretowanie, grubość, przebijanie skał, kotwienie, długość, częstotliwość, wymagania w zakresie stalowych podpór, są lepsze. Na podstawie osądów inżynieryjnych i podejść analitycznych uzyskano realistyczne środki wsparcia dla tunelu dostępowego, który ma zostać wykopany w Nilagiri, Tamil Nadu.

Nowoczesne oprogramowanie elementów skończonych umożliwia przeprowadzenie bardzo szczegółowej analizy 2D o wysokiej rozdzielczości dla realistycznych scenariuszy. Obserwuje się również zmianę w rozkładzie powyższego parametru projektowego wzdłuż przekroju poprzecznego tunelu. Przyjęte środki wsparcia projektowego są realistyczne i są analizowane za pomocą różnych metod projektowania podpór. Mogą one jednak zostać poddane nieznacznej korekcie w oparciu o szczegółową geologiczną i geotechniczną ocenę drążenia tunelu, którą należy przeprowadzić podczas budowy. W badaniu zastosowano porównanie środków wsparcia przez różnych autorów i za pomocą różnych metod oraz Plaxis 2D. Dokładne porównanie podpór za pomocą różnych metod dominujących w powszechnej praktyce pod względem konwencjonalnych przekonań również wpłynęło na końcowe środki wsparcia. Ze względu na fakt, iż zwisający ładunek znajduje się na wysokości poniżej 500 metrów nad właściwym podłożem, nie omówiono żadnych warunków przeciążania ani ściskania. Badanie to opiera się na szczegółowym projekcie realizowanym poprzez zbieranie danych terenowych oraz stosowanych danych. Jednak wariacje zostaną spełnione podczas rzeczywistego drążenia tunelu. W ramach kompromisu zalecono przeprowadzenie badań w pierwotnym miejscu jako wstępnych działań budowlanych mających na celu otrzymanie bardziej realistycznych warunków; a także, aby przede wszystkim sprawdzić obecne prace projektowe wykonywane w oparciu o dane laboratoryjne. 